\title{
The Actin Cytoskeleton is a Key Element of the Apoptosome Assembly in the Developing Brain ${ }^{\dagger}$
}

\author{
Igor Prudnikov *, Anton Smirnov and Volodymyr Tsyvkin
}

Citation: Prudnikov, I.; Smirnov, A.; Tsyvkin, V. The Actin Cytoskeleton is a Key Element of the Apoptosome Assembly in the Developing Brain. Proceedings 2021, 75, 1. https://doi.org/ 10.3390/Cells2020-08923

Published: 16 December 2020

Publisher's Note: MDPI stays neutral with regard to jurisdictional claims in published maps and institutional affiliations.

Copyright: (C) 2020 by the authors. Licensee MDPI, Basel, Switzerland. This article is an open access article distributed under the terms and conditions of the Creative Commons Attribution (CC BY) license (http://creativecommons.org/licenses /by/4.0/).

\author{
Laboratory of Stem Cell Biology, O. Bogomolets Institute of Physiology, NASU, Kyiv, 01024, Ukraine; \\ smbios@gmail.com (A.S.); kornik@ukr.net (V.T.) \\ * Correspondence: igor.prudnikov@biph.kiev.ua; Tel.: +38-067-625-52-20 \\ † Presented at the Cell-to-Cell Metabolic Cross-Talk in Physiology and Pathology, 17 December 2020-17 Jan- \\ uary 2021; Available online: https://cells2020.sciforum.net/.
}

\begin{abstract}
We investigated 2'-deoxyadenosine 5'-triphosphate (dATP) and cytochrome C-induced apoptosome formation as a source of a reliable and natural process of programmed cell death in the brain of newborn rats. We tried to find out which of the probable participants in apoptosis is responsible for the nonlinear growth of apoptosome formation at the moment of initiation of their assembly. It was found that stimulation of actin assembly by various substances, for example, Ribonuclease A (RNase A) or cations $\left(\mathrm{Na}^{+}\right.$or $\left.\mathrm{K}^{+}\right)$, leads to the induction of apoptosome formation. Actin polymerization inhibitor, cytochalasin D interferes with the stimulation of apoptosome assembly. We have shown for the first time that the organization of apoptosomes is directly related to the cytoskeleton and we propose to consider beta-actin as a key regulator of apoptosome formation, including it in the list of proteins that are critical for cell programmed death.
\end{abstract}

Keywords: dATP; cytochrome C; apoptosome; RNase A; DNase 1; nucleotides; emricasan; bortezomib

\section{Indroduction}

Cell death is a normal natural process that regulates the cell population, and it is a tool for differentiation, tissue-/organo-genesis. The most reliable evidence of apoptosis is the presence of activated executor caspases [1]. Caspases are cysteine-dependent aspartate-specific proteases that recognize (with a significant degree of specificity) the tetrapeptide -D-X-X-D- in the protein sequence and cleave them at the aspartate residue. Depending on their functions, caspases are divided into two groups, initiator and executor. Executing enzymes are at the end of the cascade and cause irreversible destruction of the cellular structure. Initiating enzymes are at the beginning of the cascade and can be activated by triggers of apoptosis [2].

Despite the fact that the events that occur during cell death are well understood, this process still contains undescribed details which require clarification. To activate caspases in vitro, as a rule, the reaction of activation of the assembly of apoptosomes with cytochrome C and dATP is used [3]. It is assumed that in the presence of these two components, the APAF-1 protein is heptamerized and, together with procaspase-9, forms apoptosomes. This protein complex plays a key role in apoptosis, because it activates caspase-9, which in turn specifically cleaves and thus turns on the executor caspases -3 , $-6,-7$, and, as a rule, if this process is activated, it cannot be returned or stopped without the use of a specific inhibitor [4].

More and more data indicate that the movement of apoptosis proteins into or out of mitochondria is extremely important for the realization of programmed cell death. Non-muscle cofilin is a member of the actin depolymerizing factor (ADF)/cofilin family 
of actin depolymerizing proteins. ADF and $n$-cofilin relocate to mitochondria during cell death by an as yet unknown mechanism. This movement depends on actin, which also relocates to the mitochondria. In experiments using iRNA of $n$-cofilin, it was found that inhibition of the synthesis of this protein leads to an interruption of cytochrome $C$ release and suppression of apoptosis [5].

Further experiments with null mutations of all ADF/cofilin isoforms showed that the release of cytochrome $C$ from mitochondria, activation of caspase-3, and apoptotic condensation of chromatin did not change in all mutant cells. Thus, the role of proteins in apoptosis that are associated with ADP release from actin, destruction of F-actin, and interact with mitochondria at the moment of apoptosis is still not clear [6]. The participation of actin in the formation of apoptosomes is not obvious also. It is assumed that $\mathrm{ADF} / \mathrm{cofilin}$ is usually not required for the induction or progression of apoptosis in mammalian cells.

We investigated cytochrome C-induced apoptosis in the brain homogenate of newborn rats as a source of a reliable and natural process of programmed cell death. We tried to find out which of the probable participants in apoptosis is responsible for the nonlinear growth of apoptosome formation at the moment of initiation of their assembly.

\section{Experiments}

The brain tissues cooled on ice were minced and homogenized according to the protocol for the isolation of intact mitochondria [7] in order to reduce the effect of endogenous cytochrome $C$ (cyt $C$ ) in an isolation medium at a ratio of $1: 2 \mathrm{w} / \mathrm{w}$, in an isotonic medium with $225 \mathrm{mM}$ sucrose, $75 \mathrm{mM}$ mannitol, $1 \mathrm{mM}$ EGTA, $20 \mathrm{mM}$ HEPES-NaOH (pH 7.4), protease inhibitors cocktail (Sigma, St. Louis, MI, USA) and 2 $\mathrm{mM}$ 1,4-dithiothreitol (DTT) at $4{ }^{\circ} \mathrm{C}$. The homogenate was centrifuged sequentially for 10 $\min$ at $1330 \times g$, and then the supernatant was centrifuged for $1 \mathrm{~h}$ at 50,000× $g$. The obtained cytoplasm was stored on ice before use.

Apoptosis was induced with buffered solution of $5 \mu \mathrm{M}$ cyt $\mathrm{C}$ and dATP $(1 \mathrm{mM})$ for 1 $\mathrm{h}$ at $32^{\circ} \mathrm{C}$. Protease reactions were performed in a volume of $200 \mu \mathrm{L}$ at $37^{\circ} \mathrm{C}$. The activity of caspase-3 was measured using the substrate (Z-Asp-Glu-Val-Asp)2-Rhodamine 110 (Z-DEVD) ${ }_{2}$ R110 in $10 \mathrm{mM}$ Tris or $30 \mathrm{mM}$ HEPES buffer, $(\mathrm{pH} 7.3)$ at $\lambda_{\mathrm{ex}}=485 \mathrm{~nm}$ and $\lambda_{\mathrm{em}}=$ $535 \mathrm{~nm}$. (Z-DEVD) ${ }_{2}$ R110 as a substrate was used to measure caspase activity together with $20 \mu \mathrm{M}$ bortezomib or $2 \mu \mathrm{M}$ AdaAhx ${ }_{3} \mathrm{~L}_{3} \mathrm{VS}$ to reduce background proteasomal activity. Emricasan was added to confirm caspases' specificity [8].

Cytoplasm was fractionated by high molecular weight gel filtration with HW-65 (Supelco, Japan) on a column of $50 \mathrm{~cm} \times 1 \mathrm{~cm}$, at the rate of $0.3 \mathrm{~mL} / \mathrm{min}$. Each fraction was re-concentrated on $150 \mathrm{kDa}$ filters (Millipore, Burlington, MA, USA).

Nucleic acids (nuclear DNA, mitochondrial DNA, total RNA, mRNA, tRNA) were isolated from brain lysate of newborn rats according to the manufacturer's protocol (Qiagen, Valencia, CA, USA). Yeast tRNA was purified from a commercial preparation (Millipore, USA) by ion-exchange chromatography on DEAE-Sepharose according to a well-known protocol. The concentration of nucleic acids was determined spectrophotometrically.

F- and G-actin were purified from the newborn and adult rat brains according to the earlier described method [9].

A modified Bradford method [10] and 3-(4-carboxybenzoyl)quinoline-2-carboxaldehyde (CBQCA) Protein Quatitation Kit (Invitrogen, Carlsbad, CA, USA) were used to determine the protein concentration.

\section{Results}

Measurement of the emricasan-depended activity [11] (Z-DEVD) 2 R110-ase, which are not inhibited with $20 \mu \mathrm{M}$ bortezomib (or $2 \mu \mathrm{M}$ AdaAhx $3 \mathrm{~L}_{3} \mathrm{VS}$ ) in lysates of newborn rats' brains after adding of cyt $\mathrm{C}$ and dATP, showed that it exists only in the cytoplasm 
and is absent in membranes (data not shown). It was found that the addition of cations to the reaction mixture significantly increases the activity of caspases, and the protein concentration is essential. For example, $V_{\max }$ was $60 \pm 12$ and $172 \pm 14 \mathrm{nmol} / \mathrm{mg}$ protein/min, and $\mathrm{K}_{\mathrm{m}}$ for the substrate was $4.2 \pm 0.1$ and $1.25 \pm 0.17 \mu \mathrm{M}$, at a protein concentration of 3.75 and $5.5 \mathrm{mg} / \mathrm{mL}$, respectively. The addition of $40 \mathrm{mM} \mathrm{KCl}$ to the reaction mixture led to a significant change in both $\mathrm{V}_{\max }-1300 \pm 120$ and $2400 \pm 100 \mathrm{nmol} / \mathrm{mg}$ protein/min, and $\mathrm{K}_{\mathrm{m}}-0.56 \pm 0.1$ and $0.13 \pm 0.05 \mu \mathrm{M}$, for 3.75 and $5.5 \mathrm{mg} / \mathrm{mL}$ of protein, respectively. The dependence of activity on protein concentration was exponential (Figure 1).

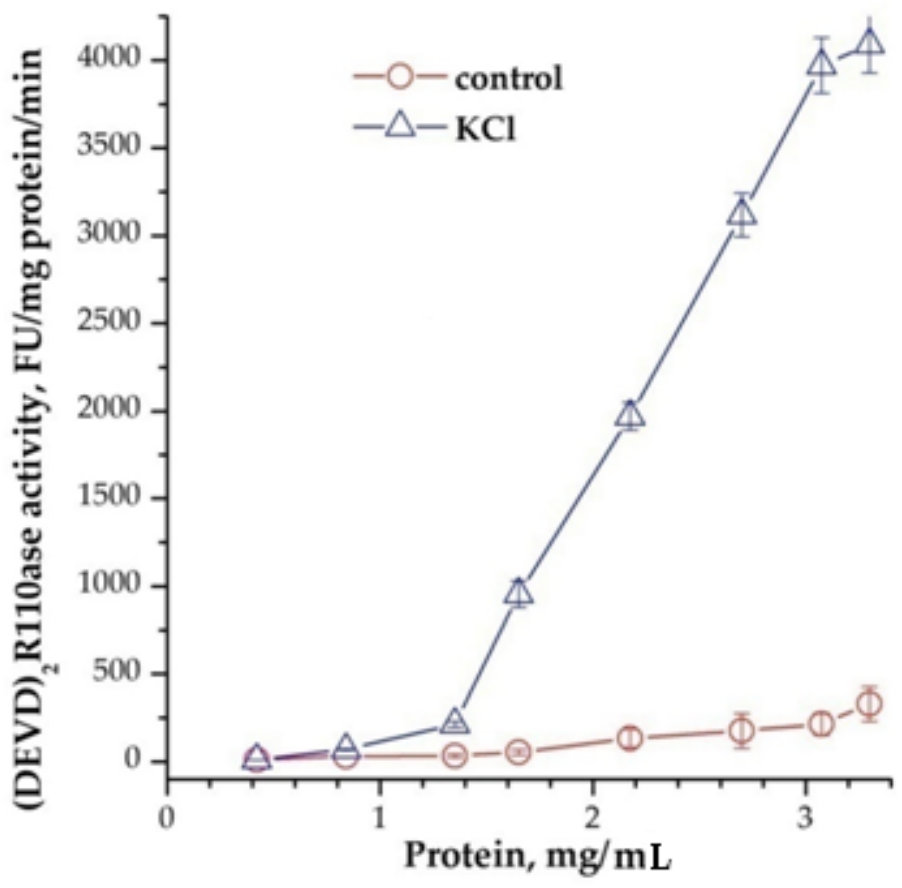

Figure 1. Dependence of the formation of apoptosomes from concentration of cytoplasmic protein. $40 \mathrm{mM} \mathrm{KCl}$ was added $15 \mathrm{~min}$ before adding of cytochrome $\mathrm{C}$ and dATP. In control was added the buffer. Data are presented as mean $\pm \mathrm{SD}, n=3$.

Cations in a dose-dependent manner stimulated the activity of caspases, but only when added before or together with inducers of apoptosome formation, while 30-40 mM potassium or sodium had the maximum effect (Figure 2).

After the reaction of induction of the formation of apoptosomes, the addition of monovalent cations did not change the activity of caspases. Concentration-dependent inhibition was also observed in the range of $90-120 \mathrm{mM}$ if cations were added before and no effect if added after activation (Figure 2). Replacing sodium or potassium chlorides with NMDG-Cl at the same concentrations had no effect. The use of K-, Na-MOPS instead of chlorine salts did not fundamentally change the character of stimulation with cations, but shifted the maximum of activation magnitude on $10 \mathrm{mM}$ to the left - up to 30 $\mathrm{mM}$ (data not shown).

The addition of plasma membranes had a similar effect to cations, significantly increasing the number of activated caspases and the affinity for the substrate. For example, for the case with a protein concentration in the cytoplasm equal to $3.75 \mathrm{mg} / \mathrm{mL}, V_{\max }$ increased from $60 \pm 12$ to $1100 \pm 220 \mathrm{nmol} / \mathrm{mg}$ protein $/ \mathrm{min}$, and $\mathrm{K}_{\mathrm{m}}$ decreased in more than 2 folds. In this case, the addition of cations to the reaction mixture with membranes had an additive effect. All the membranes that we tried had an effect: plasma membranes from the brains of adult and newborn rats, membranes from the heart tissue and the erythrocyte ghosts. As in the case with other inducers of apoptosis, the membranes effected prior to activation of apoptosome assembly mainly (Figure 3). 


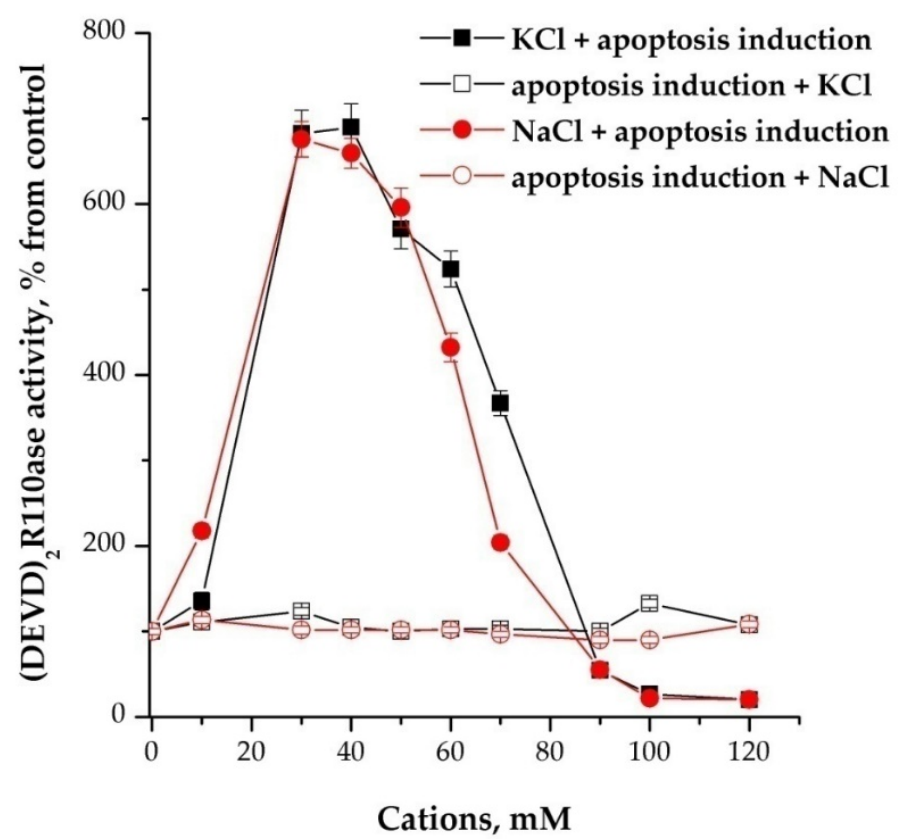

Figure 2. Cation dependence of the formation of apoptosomes. Concentration of cytoplasmic protein was equal to $2 \mathrm{mg} / \mathrm{mL}$. $\mathrm{NaCl}$ and $\mathrm{KCl}$ were added $15 \mathrm{~min}$ before the induction of formation of apoptosomes. In control, $\mathrm{NaCl} / \mathrm{KCl}$ were added after the induction and probes were incubated more for $15 \mathrm{~min}$. Data are presented as mean $\pm \mathrm{SD}, n=3$.

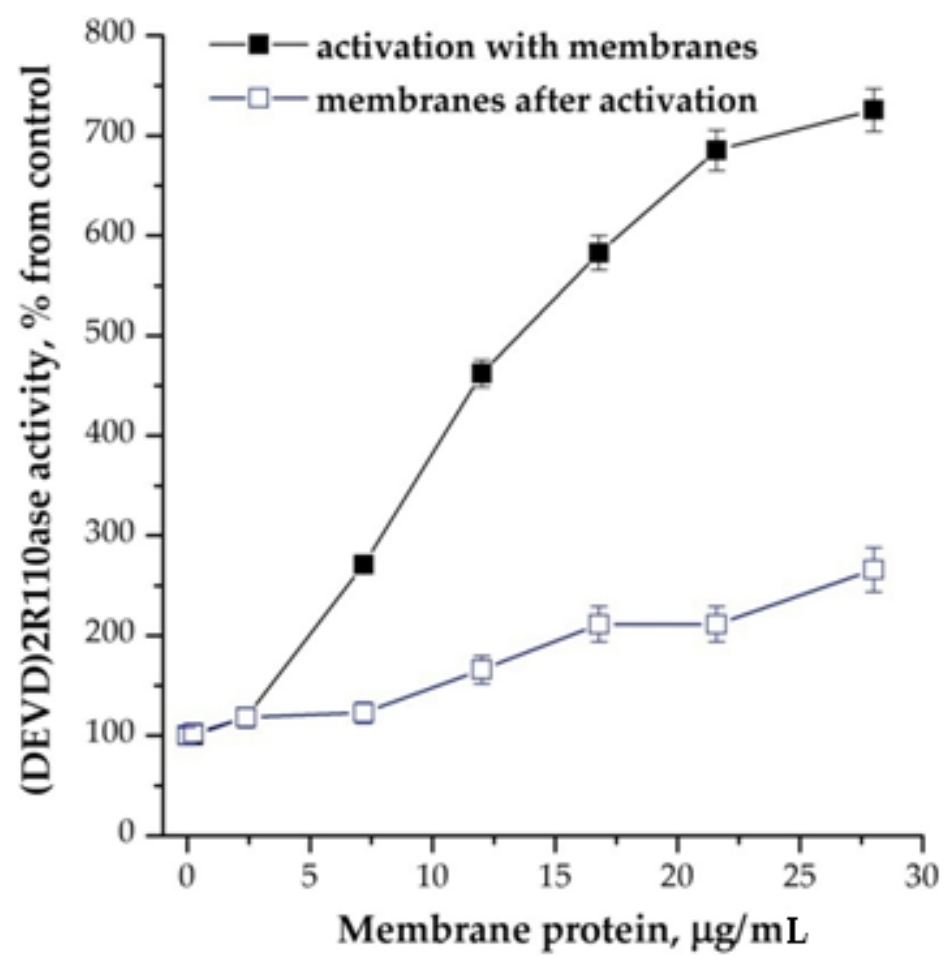

Figure 3. Dependence of the formation of apoptosomes from the presence of membranes from brain cortex of newborn rats. Concentration of cytoplasmic protein was equal to $2 \mathrm{mg} / \mathrm{mL}$. The membranes were added $15 \mathrm{~min}$ before the induction of formation of apoptosomes. In control, the membranes were added after the induction and probes were incubated more for $15 \mathrm{~min}$. Data are presented as mean $\pm \mathrm{SD}, n=3$.

Other potential regulators of caspase activity may be inhibitor proteins, in particular cellular inhibitor of apoptosis protein/X-linked inhibitor of apoptosis protein (IAP/XIAP) [12]. We used several structural inhibitors of IAP/XIAPs, and one of them, LCL 161, 
turned out to be the most effective stimulator of caspase activity. Its use did not significantly change the mode of cation dependence (Figure 4). This drug also stimulated caspase activity after the induction of apoptosome formation. The mitochondrial protease inhibitor HtrA2/Omi had no effect on the process under study (data not shown).

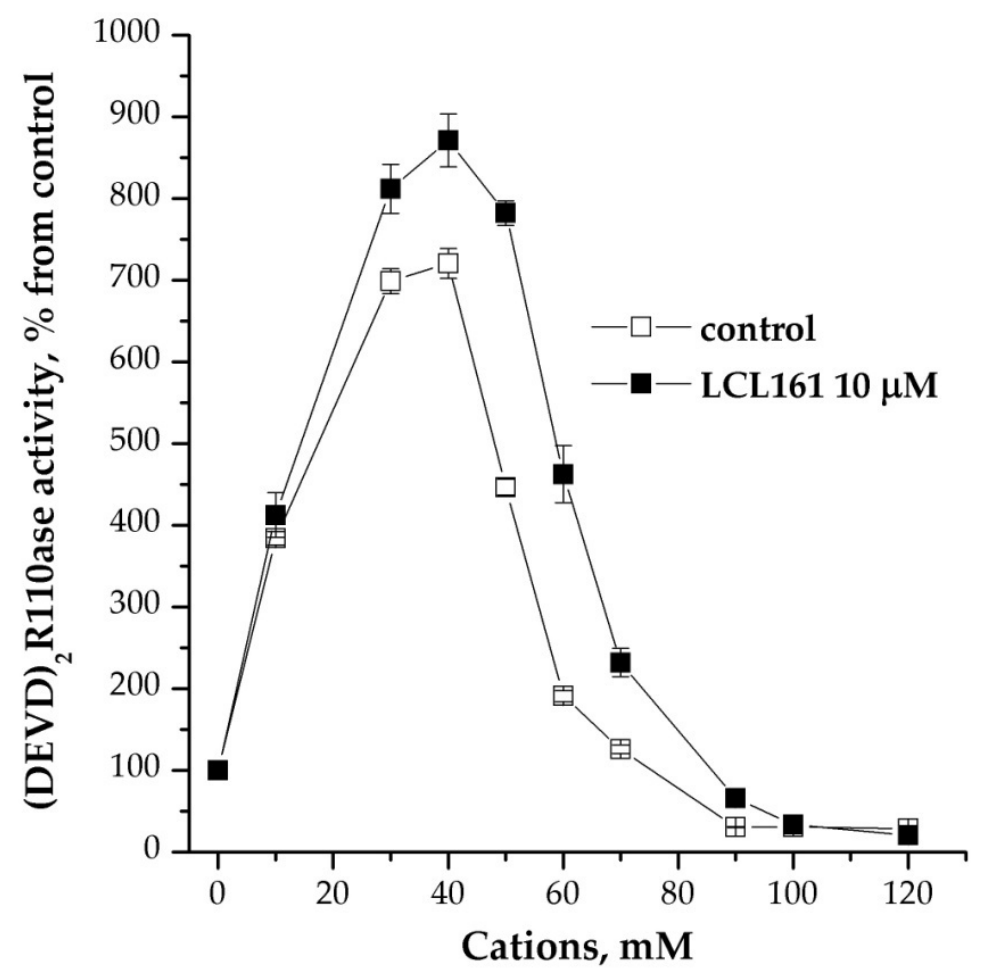

Figure 4. Effect of inhibitor of IAP/XIAP proteins on cation dependence of formation of apoptosomes. Concentration of cytoplasmic protein was equal to $2 \mathrm{mg} / \mathrm{mL} ; 10 \mu \mathrm{M} \mathrm{LCL} 161$ and $\mathrm{KCl}$ were added $15 \mathrm{~min}$ before the induction of formation of apoptosomes. In control, $\mathrm{KCl}$ was added before the induction and probes were incubated more for $15 \mathrm{~min}$. Data are presented as mean $\pm \mathrm{SD}, n=3$.

We assumed that these effects can be explained by the actin state [13]. Actin polymerization inhibitor, cytochalasin D partially inhibited the induction of apoptosis (Figure 5). This compound reduced the dependence of the DEVDase activity of the cytoplasm on actin, but the pattern of activation of caspase assembly and an increase in their activity was reproduced, and the peak of the maximum efficiency was at the same potassium concentrations as without cytochalasin D. Inhibitors of microtubule formation colchicine and vinblastine had no effect. This observation indicates a potential involvement of actin in the activation of caspase-9/3.

We used actin depleted cytoplasm after induction of its polymerization with 100 $\mathrm{mM} \mathrm{KCl}$. A half-hour preincubation of cytoplasm samples at a protein concentration of more than $2.5 \mathrm{mg} / \mathrm{mL}$ with $100 \mathrm{mM} \mathrm{KCl}$ makes it impossible to further induce apoptosis. In this case, fibrillar actin was separated by high-speed centrifugation, and the cytoplasm from the supernatant was concentrated. 


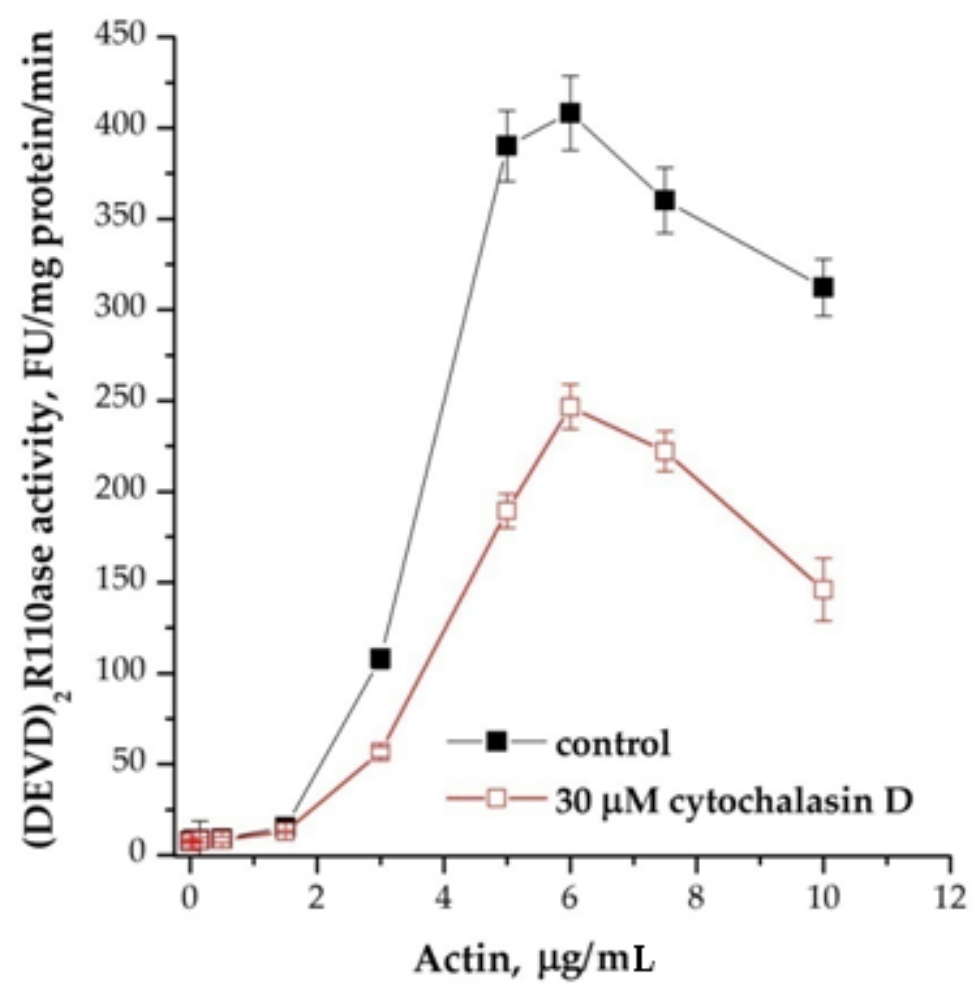

Figure 5. Effect of cytochalasin D on cation dependence of the formation of apoptosomes. Concentration of cytoplasmic protein was equal to $1.75 \mathrm{mg} / \mathrm{mL} ; 30 \mu \mathrm{M}$ cytochalasin $\mathrm{D}$ at $4{ }^{\circ} \mathrm{C}$ was added 1 $\mathrm{h}$ before the induction, $\mathrm{KCl}$ was added $15 \mathrm{~min}$ before the induction of formation of apoptosomes. In control, $\mathrm{KCl}$ was added before the induction, and probes were incubated more for $15 \mathrm{~min}$. Data are presented as mean $\pm \mathrm{SD}, n=3$.

In order to decrease the $\mathrm{KCl}$ concentration to values at which it does not noticeably affect the induction of caspase activity after $\mathrm{KCl}$, the cytoplasm was diluted 15 times before concentrating. The same manipulations with dilution and concentration were carried out with the control cytoplasm. There was no (Z-DEVD) $)_{2}$ R110-ase activity after this procedure with $\mathrm{KCl}$. Purified actin partially restored the ability of such cytoplasm to be activated by inductors, but complete recovery was not observed. To manipulate the ratio of F- and G-form of actin in the cytoplasm, we used RNase and/or DNase.

It is known that DNase binds G-actin in an equimolar ratio, and RNase induces the formation of F-actin [14,15]. The effects of F-actin (polymerized form) and G-actin (mono-form) in their influence on the activity of caspases are opposite. Experiments have shown that F-actin stimulates and G-actin inhibits activity in a dose-dependent manner (Figure 6). This observation confirms our previous assumption about the connection between the caspases' activation and actin. It is known that the assembly of monomeric G-actin into filamentous F-actin depends on nucleotides: ATP bound G-actin is present at the growing "barbed end" of F-actin, whereas after hydrolysis of phosphate, ADP bound G-actin dissociates from the "pointed" end. The addition of di- and triphosphate nucleotides to the cytoplasm prior to the induction of apoptosome assembly showed an obvious tendency to inhibition of the process of apoptosome formation. In contrast to the situation described above, RNase A in combination with nucleotides stimulated the reaction (Figure 7). The strongest stimulation by RNase A was observed with the use of ADP, while ATP and GDP also had an effect, but it was noticeably less. The addition of GTP did not affect the efficiency of induction (data not shown). 


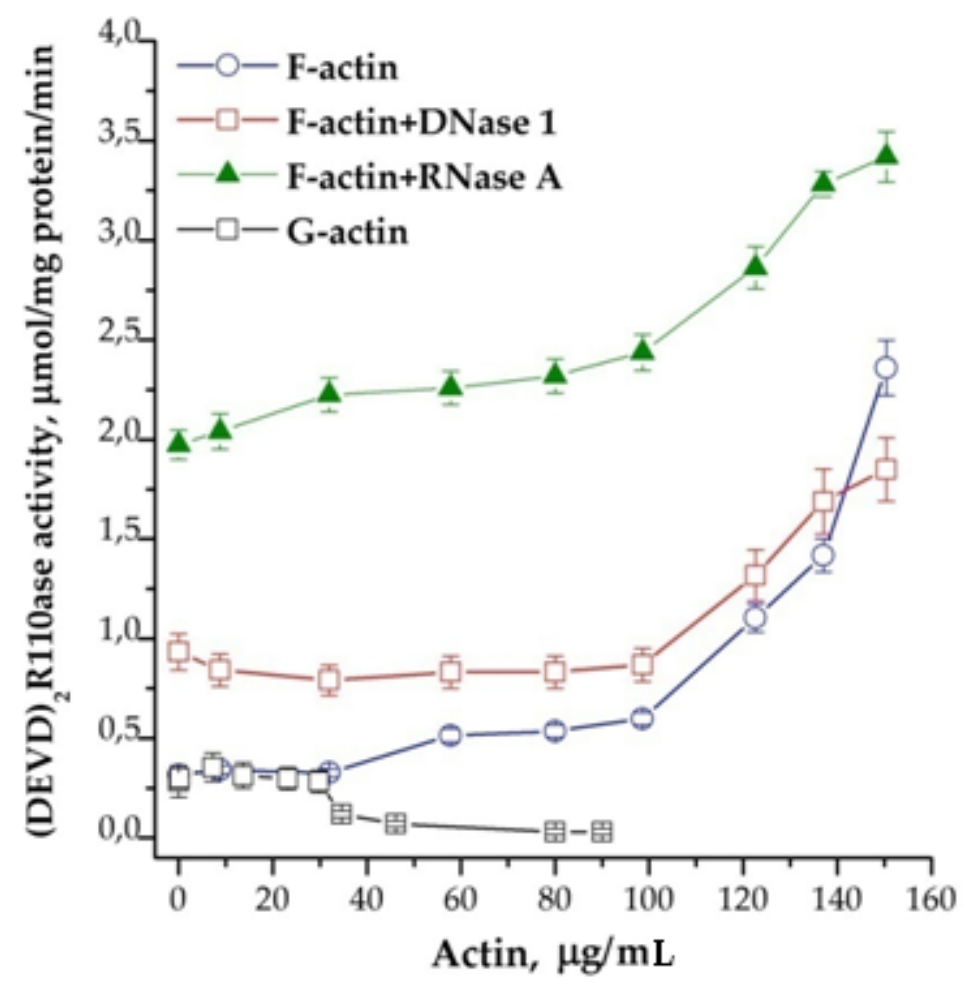

Figure 6. Dose-dependence of the formation of apoptosomes from actin in different forms. Concentration of cytoplasmic protein was equal to $1.75 \mathrm{mg} / \mathrm{mL}$. Actin in different concentrations and 2 $\mu \mathrm{g}$ of DNase 1 or $10 \mu \mathrm{g}$ of RNase A on $100 \mu \mathrm{g}$ of cytoplasmic protein were added $30 \mathrm{~min}$ before the induction. Data are presented as mean $\pm \mathrm{SD}, n=3$.

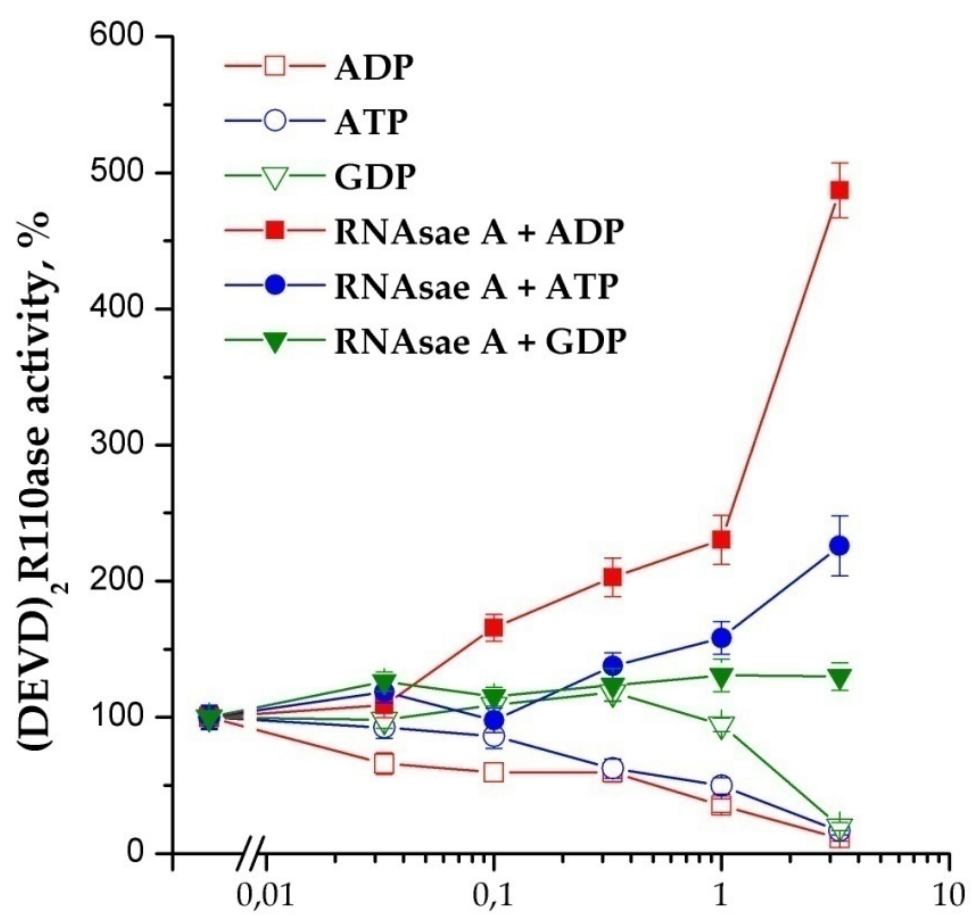

Nucleotide, $\mathrm{mM}$

Figure 7. The influence of RNase A on nucleotide-dependence of the apoptosome formation. Concentration of cytoplasmic protein was equal to $1.75 \mathrm{mg} / \mathrm{mL}$. Nucleotides were added $40 \mathrm{~min}$ before the induction; $10 \mu \mathrm{g}$ of RNase A on $100 \mu \mathrm{g}$ of cytoplasmic protein was added $30 \mathrm{~min}$ before the induction. Data are presented as mean $\pm \mathrm{SD}, n=3$. 
It is known that tRNA inhibits the assembly of apoptosomes in vitro; it is possible that in cells it also serves as a natural inhibitor of apoptosis $[16,17]$. We tested total RNA, mRNA, and tRNA from the brains of adult and newborn rats, yeast tRNA, as well as genomic and mitochondrial DNA. Only inhibition of the induction of apoptosome formation by nucleic acids was found at nucleic acid concentrations starting from $0.1 \mu \mathrm{g} / \mathrm{mL}$ with a plateau effect at concentrations from $1 \mu \mathrm{g} / \mathrm{mL}$. After induction of apoptosome assembly, nucleic acids had no effect on caspase activity. Gel filtration was used to estimate the molecular weight of apoptosomes whose assembly was induced by cytochrome $\mathrm{C}$ and dATP. A single peak (800-500 kDa) of emricasan-sensitive caspase activity coincided with the distribution profile of particles of $20 S$ proteasome. The same data were obtained in the case of cytoplasm fractionation after inducing to the formation of apoptosomes by cations, membrane preparations, or ADP + RNase. Gel chromatography of non-induced cytoplasm made it possible to isolate a protein fraction of $800-500 \mathrm{kDa}$. As a result of concentrating of this fraction, a sample was obtained in which cytochrome $\mathrm{C}$ and dATP could also induce caspase activity if the protein concentration was not less than 2.5 $\mathrm{mg} / \mathrm{mL}$. This activity was $2-5 \%$ of the caspase activity induced to apoptosis before separation.

\section{Discussion}

Apoptosis includes many participants that are involved in interaction with caspases and triggers of apoptosis, and energy resources are required for its execution. The last consideration concerns the fact that ATP is required for the formation of apoptosomes. The only parameter that unambiguously indicates the appearance of apoptosis is the formation of apoptosomes [1].

We investigated the formation of these structures, considering what is happening from the point of view of the state of the cytoskeleton. It turned out that the exponential increase in the formation of apoptosomes with an increase in the concentration of the cytoplasmic protein is fully explained by the induction of the formation of F-actin.

Studies have been performed by the method of immunoprecipitation of caspase- 9 and subsequent mass spectroscopic analysis of proteins directly associated with this protease. It was found that caspase-9 interacts differently with various proteins before and after activation of apoptosome assembly. In an inactive state, caspase-9 binds to cytoskeletal proteins and histones. In the active state, it binds to APAF- 1 and other proteins that have proapoptotic functions, as well as with transcription factors and enzymes of carbohydrate metabolism [18]. It should be noted that out of 20 identified proteins associated with inactivated caspase $-9,12$ belong to the system of actin filaments or are closely associated with actin or are part of the actin cytoskeleton. After activation of caspase- 9 by cytochrome $\mathrm{C}$ and $\mathrm{dATP}$, only 7 proteins that are not associated with the cytoskeleton are in close coupling to caspase-9 [18].

Many of the substances and proteins which we used effect the assembly/disassembly of actin filaments. For example, the reversal of the inhibitory effect of ADP by RNase A indicates the involvement of an unidentified important participant in the assembly of apoptosomes. We found that a certain state of actin filaments is necessary for the assembly of apoptosomes. A change in balance towards a predominance of $\mathrm{G}$-actin inhibits the formation of apoptosomes. Conversely, the dominance of F-actin (in the presence of cations and ADP + RNase A) increases the number of active caspases and their affinity for the substrate in $60-80$ folds (i.e., significantly enhances the activity of these proteases). A similar effect is exerted by the presence of membranes, whose proteins can be triggers of the assembly of actin filaments [14,15]. The described effect does not affect the molecular size of apoptosomes and it is not associated with caspase inhibitor proteins, such as IAP/XIAP.

The monomeric or fibrillar state of actin influences its interaction with other actin molecules and actin-binding proteins. The $\mathrm{W}$-loop of the actin molecule is a nucleotide sensor that regulates changes in actin depending on the nucleotide state [19]. We assume 
that, opposite in character, the effects of nucleotides upon stimulation of the formation of actin filaments could be indicated that proteins interacting with actin are involved in the formation of apoptosomes. The place of their location is possibly the point end of actin filaments. At the same time, the nucleotide-binding site of actin stabilizes actin in the ADP form [19]. Subsequent activation of F-actin polymerization by cytochrome C leads to the induction of apoptosome formation. We can only imagine the outline of what is happening, but this explains the phenomena that until then was difficult to analyze. For example, it could be assumed that nucleic acids compete with cytochrome $C$ in the binding of the latter to actin, since tRNAs in apoptosomes are known to closely interact with cytochrome C [17].

We have shown for the first time that the organization of apoptosomes is directly related to the cytoskeleton and we propose to consider beta-actin as a key regulator of apoptosome formation, including it in the list of proteins that are critical for cell programmed death.

Author Contributions: I.P., A.S., and V.T. conceived and designed the experiments, performed the ones, analyzed the data and wrote the paper. All authors have read and agreed to the published version of the manuscript.

Institutional Review Board Statement: Not applicable.

Informed Consent Statement: Not applicable.

Data Availability Statement: The datasets generated and analyzed during the current study are available from the corresponding author on a reasonable request.

Acknowledgments: The reported study was funded by National Academy of Sciences of Ukraine according to the research project № II-1-20, 0120U001281.

Conflicts of Interest: The authors declare no conflicts of interest. The founding sponsors had no role in the design of the study; in the collection, analyses, or interpretation of data; in the writing of the manuscript, and in the decision to publish the results.

$\begin{array}{ll}\text { Abbreviations } & \\ \text { dATP } & \text { 2'-deoxyadenosine } \text { 5'-triphosphate }^{\prime} \\ \text { RNase A } & \text { Ribonuclease A } \\ \text { DTT } & \text { 1,4-dithiothreitol } \\ \text { cyt C } & \text { cytochrome C } \\ \text { HtrA2/Omi } & \text { high temperature requirement protein A2 serine protease } \\ \text { IAP } & \text { cellular inhibitor of apoptosis protein } \\ \text { XIAP } & \text { X-linked inhibitor of apoptosis protein } \\ \text { APAF-1 } & \text { apoptotic peptidase activating factor 1 } \\ \text { ADF } & \text { actin depolymerizing factor } \\ \text { CBQCA } & \text { 3-(4-carboxybenzoyl)-2-quinolinecarboxaldehyde } \\ \text { (Z-DEVD) } 2 \text { R110 } & \text { (Z-Asp-Glu-Val-Asp) } 2 \text {-Rhodamine 110 } \\ \text { AdaAhx }{ }_{3} \text { L }_{3} \text { VS } & \text { adamantane-acetyl-(6-aminohexanoyl) }{ }_{3} \text {-(leucinyl) }{ }_{3} \text {-vinyl-(methyl)-sulfone }\end{array}$

\section{References}

1. Mandhair, H.K.; Arambasic, M.; Novak, U.; Radpour, R. Molecular modulation of autophagy: New venture to target resistant cancer stem cells. World J. Stem. Cells 2020, 12, 303-322, doi:10.4252/wjsc.v12.i5.303.

2. Gorman, A.M.; Hirt, U.A.; Zhivotovsky, B.; Orrenius, S.; Ceccatelli, S. Application of a fluorometric assay to detect caspase activity in thymus tissue undergoing apoptosis in vivo. J. Immunol. Methods 1999, 226, 43-48, doi:10.1016/s0022-1759(99)00054-x.

3. Liu, X.; Kim, C.N.; Yang, J.; Jemmerson, R.; Wang, X. Induction of apoptotic program in cell-free extracts: Requirement for dATP and cytochrome C. Cell 1996, 86, 147-157, doi:10.1016/s0092-8674(00)80085-9.

4. Zou, H.; Li, Y.; Liu, X.; Wang, X. An APAF-1. Cytochrome C multimeric complex is a functional apoptosome that activates procaspase-9. J. Biol. Chem. 1999, 274, 11549-11556, doi:10.1074/jbc.274.17.11549. 
5. Chua, B.T.; Volbracht, C.; Tan, K.O.; Li, R.; Yu, V.C.; Li, P. Mitochondrial translocation of cofilin is an early step in apoptosis induction. Nat. Cell Biol. 2003, 5, 1083-1089, doi:10.1038/ncb1070.

6. Rehklau, K.; Gurniak, C.B.; Conrad, M.; Friauf, E.; Ott, M.; Rust, M.B. ADF/cofilin proteins translocate to mitochondria during apoptosis but are not generally required for cell death signaling. Cell. Death Differ. 2012, 19, 958-967, doi:10.1038/cdd.2011.180.

7. Kristian, T. Isolation of mitochondria from the CNS. Curr. Protoc. Neurosci. 2010, 52, 7-22, doi:0.1002/0471142301.ns0722s52.

8. Prudnikov, I.M.; Smirnov, A.N. Short peptide tools for monitoring caspase and proteasome activities in embryonal and adult rat brain lysates: An approach for the differential identification of proteases. J. Biochem. 2012, 151, 299-316, doi:10.1093/jb/mvs001.

9. Levilliers, N.; Peron-Renner, M.; Coffe, G.; Pudles, J. Actin purification from a gel of rat brain extracts. Biochimie 1984, 66, 531-537, doi:10.1016/0300-9084(84)90147-0.

10. Splittgerber, A.G.; Sohl, J. Nonlinearity in protein assays by the Coomassie blue dye-binding method. Anal. Biochem. 1989, 179, 198-201, doi:10.1016/0003-2697(89)90225-x.

11. Hoglen, N.C.; Chen, L.S.; Fisher, C.D.; Hirakawa, B.P.; Groessl, T.; Contreras, P.C. Characterization of IDN-6556 (3-[2-(2-tert-butyl-phenylaminooxalyl)-amino]-propionylamino]-4-oxo-5-(2,3,5,6-tetrafluoro-phenoxy)-pentanoic acid): A liver-targeted caspase inhibitor J. Pharmacol. Exp. Ther. 2004, 309, 634-640, doi:10.1124/jpet.103.062034.

12. Ohoka, N.; Ujikawa, O.; Shimokawa, K.; Sameshima, T.; Shibata, N.; Hattori, T.; Nara, H.; Cho, N.; Naito, M. Different Degradation Mechanisms of Inhibitor of Apoptosis Proteins (IAPs) by the Specific and Nongenetic IAP-Dependent Protein Eraser (SNIPER). Pharm. Bull. 2019, 67, 203-209, doi:0.1248/cpb.c18-00567.

13. Prentki, M.; Chaponnier, C.; Jeanrenaud, B.; Gabbiani, G. Actin microfilaments, cell shape, and secretory processes in isolated rat hepatocytes. Effect of phalloidin and cytochalasin D. J. Cell Biol. 1979, 81, 592-607, doi:10.1083/jcb.81.3.592.

14. Simm, F.C.; Krietsch, W.K.; Isenberg, G. On the interaction of bovine seminal RNase with actin in vitro. Eur. J. Biochem. 1987, 166, 49-54, doi:10.1111/j.1432-1033.1987.tb13482.x.

15. Mannherz, H.G.; Leigh, J.B.; Leberman, R.; Pfrang, H. A specific 1:1 G-actin: DNAase I complex formed by the action of DNAase I on F-actin. FEBS Lett. 1975, 60, 34-38, doi:10.1016/0014-5793(75)80412-1.

16. Mei, Y.; Yong, J.; Liu, H.; Shi, Y.; Meinkoth, J.; Dreyfuss, G.; Yang, X. tRNA binds to cytochrome c and inhibits caspase activation. Mol. Cell. 2010, 37, 668-678, doi:10.1016/j.molcel.2010.01.023.

17. Lo, Y.-T.; Huang, H.-W.; Huang, Y.-C.; Chan, J.-F.; Hsu, Y. H. H. Elucidation of tRNA-cytochrome c interactions through hydrogen/deuterium exchange mass spectrometry. Biochim. Biophys. Acta Proteins Proteom. 2017, 1865, 539-546, doi:10.1016/j.bbapap.2017.02.015.

18. Chęcińska, A.; Giaccone, G.; Rodriguez, J.A.; Kruyt, F.A.; Jimenez, C.R. Comparative proteomics analysis of caspase-9-protein complexes in untreated and cytochrome c/dATP stimulated lysates of NSCLC cells. J. Proteom. 2009, 72, 575-578, doi:10.1016/j.jprot.2008.11.016.

19. Kudryashov, D.S.; Grintsevich, E.E.; Rubenstein, P.A.; Reisler, E. A nucleotide state-sensing region on actin. J. Biol. Chem. 2010, 285, 25591-25601, doi:10.1074/jbc.M110.123869. 